\title{
Łacina w późnośredniowiecznej Warszawie Kilka uwag na temat książki Urszuli Zachary-Związek Łacina późnośredniowiecznych ksiąg ławniczych Starej Warszawy (Warszawa 2019, 111 s.)*
}

\author{
The Latin in Late Medieval Warsaw \\ Some Comments on the Book of Urszula Zachara-Związek \\ Łacina późnośredniowiecznych ksiąg ławniczych Starej Warszawy \\ (Warszawa 2019, 111 pp.)
}

Książka Urszuli Zachary-Związek Łacina późnośredniowiecznych ksiąg ławniczych Starej Warszawy wpisuje się $w$ szeroki nurt badań nad różnymi aspektami łaciny średniowiecznej i dotyczy zagadnień dotychczas nieomawianych w literaturze językoznawczej. Autorka przeprowadziła wnikliwą analizę czterech warszawskich ksiąg ławniczych z lat 1453-1535, oddając do rąk czytelników rzetelną charakterystykę języka łacińskiego, jakim posługiwano się w kancelarii miejskiej Starej Warszawy w późnym średniowieczu. Księgi ławnicze, należące do piśmiennictwa pragmatycznego, odznaczały się - jak słusznie zauważa Autorka własną specyfiką językową (s. 11). Stanowiły zatem bardzo dobre źródło do badań nie tylko ogólnych i typowych dla łaciny średniowiecznej cech, ale również indywidualnych właściwości urzędowej produkcji piśmienniczej średniowiecznej Warszawy. Dzięki tak wyselekcjonowanemu pod względem generycznym, czasowym i miejscowym materiałowi Autorce udało się jednak nie tylko zaprezentować ustalenia i wnioski natury językoznawczej, ale także na ich podstawie poczynić pewne spostrzeżenia dotyczące kancelarii Starej Warszawy w ogóle. Zachara-Związek trafnie bowiem zauważyła powiązanie między stopniem sprawności językowej zatrudnianych $w$ kancelarii pisarzy a poziomem organizacyjnym tego urzędu (s. 8). Na uwagę zasługuje także fakt, że rozprawa stanowi uzupełnienie edycji ksiąg ławniczych Starej Warszawy, nad których wydaniem pracowała również sama Autorka (por. BARtoszewicz, 2020). Zachara-Związek musiała więc wykazać się nie tylko solidnym warsztatem filologicznym, lecz także gruntowną wiedzą paleograficzną, gdyż praca powstała na podstawie wówczas jeszcze niewydanych manuskryptów.

Poza sprecyzowanym celem badawczym i starannie dobranym materiałem publikacja odznacza się przejrzystą strukturą, na którą składają się cztery główne części poświęcone kolejno grafii, fleksji, składni oraz relacjom między łaciną a językami wernakularny-

* Niniejsza publikacja jest finansowana $w$ ramach programu Ministra Nauki i Szkolnictwa Wyższego pod nazwą „Narodowy Program Rozwoju Humanistyki” w latach 2018-2023, nr projektu 0116/NPRH6/H11/85/2018 (Elektroniczny korpus polskiej łaciny średniowiecznej. Kontynuacja prac), kwota finansowania $1,8 \mathrm{mln}$ zł. 
mi (polskim i niemieckim). Całość poprzedzona została wstępem językowo-historycznym, w którym przedstawiono ogólną charakterystykę łaciny średniowiecznej ze szczególnym uwzględnieniem etapów rozwoju języka od starożytności do wieków średnich, organizację samorządu miejskiego w średniowieczu, sylwetki pisarzy-redaktorów analizowanych $w$ pracy ksiąg, a także informacje na temat wykorzystanych rękopisów. Zachara-Związek wykazała się dużą znajomością literatury przedmiotu odnoszącej się do aspektów zarówno językowych, jak i historycznych, o czym świadczy zamieszczona na końcu książki obszerna bibliografia. W analizie poszczególnych aspektów językowych Autorka skupiła się przede wszystkim na zjawiskach charakterystycznych dla języka ksiąg ławniczych Starej Warszawy, wskazując, które z nich należą do indywidualnych właściwości konkretnej księgi, a które uznać można za wpisujące się w ogólne (nie)prawidłowości łaciny średniowiecznej. Uprawnione jest tutaj użycie określenia „nieprawidłowości” - Zachara-Związek owe cechy językowe rozpatruje bowiem głównie w perspektywie odstępstwa od normy klasycznej, omawiając je na tle ogólnych tendencji rozwojowych języka łacińskiego w wiekach średnich (por. NoWAK, 2017: 170-171).

Analizując $w$ rozdziale pierwszym cechy pisowni, Autorka zauważa, że „w czasie, którego dotyczą prezentowane rozważania, łacina stanowiła dla wszystkich jej użytkowników jedynie język obcy, wyuczony, więc nie powinna już była podlegać przemianom fonetycznym" (s. 32). Dlatego też przyjęła formułowane także przez innych badaczy założenie, zgodnie $z$ którym zjawiska fonetyczne występujące $w$ łacinie średniowiecznej można analizować w bezpośrednim związku z pisownią, uznając ją za dość pewną wskazówkę do szukania wartości fonetycznej różnych głosek (Weyssenfoff-BrożkowA, 1998: 17). Do charakterystycznych cech pisowni ksiąg ławniczych Starej Warszawy zaliczyła częste użycie litery $w$ zamiast $v$ (np. prewignus, parwus, wult, awunculus), zastosowanie litery y zamiast $i$ (szczególnie w wyrażeniu pye memorie), używanie prostej formy przyimka a przed samogłoską zamiast skutkującego uniknięciem hiatu wariantu ab (a orto, a omnibus) oraz zapis $c z$ zamiast $c$ przed głoskami $e$ oraz $i$ (np. paczem habere), co może świadczyć o spalatalizowanej wymowie $c$. Ciekawy wniosek dotyczący wymowy Autorka wyciągnęła również z częstego zapisywania litery y zamiast $i \mathrm{w}$ - jak pisze - sąsiedztwie l (np. wlycza / vlycza, Lywensis, Kylian, Philyppus, fylia, pyleator, lyber, lybenter, nichyl, soly), zauważając tutaj możliwy wpływ dialektu mazowieckiego z charakterystycznym dla niego brakiem zmiękczenia głoski l (s. 36-37). Należy jednak doprecyzować, że o oddziaływaniu dialektu mazowieckiego wnioskować można $w$ przypadku, gdy $y$ występuje $w$ pozycji po $l$, a nie ogólnie w sąsiedztwie 1 . Stąd też przykłady Kylian, fylia, pyleator, nichyl należałoby wydzielić i zaznaczyć, że nie chodzi $w$ ich przypadku o wpływy dialektalne. Zachara-Związek zaobserwowała ponadto zastępowanie dwuznaku qu literą $c$ - na tej podstawie wysunęła poparty wieloma przykładami wniosek, że wskazany dwuznak wymawiano - a przynajmniej tak wymawiał go pisarz - jako $k$ (np. condam = quondam, cociens $=$ quociens, covis $=$ quovis $)$. Podobnie opierając się na zapisach imienia Georgius jako Jeorgius, stwierdziła, że głoskę $g$ przed $e$ oraz $i$ wymawiano jako niezgłoskotwórcze $i$ - była to jednak tendencja występująca również $w$ innych tekstach polskiej łaciny średniowiecznej. Do takich ogólnych, powszechnie występujących $w$ łacinie średniowiecznej zjawisk Autorka zaliczyła ponadto: zapisywanie dyftongów ae i oe jako $e$ (na skutek monoftongizacji), asybilację $t$ przed $i$ (zapis -cio zamiast -tio), niekonsekwencje $w$ zapisie spółgłosek gemino- 
wanych, epentezę spółgłosek oraz mylenie głosek dźwięcznych i bezdźwięcznych (np. aput zamiast apud).

W rozdziale drugim Zachara-Związek zaprezentowała zagadnienie fleksji. Wprawdzie łacina średniowieczna zachowała klasyczny system fleksyjny, Autorka jednak zaobserwowała $w$ omawianych tekstach pewne odstępstwa od normy starożytnej w zakresie zarówno deklinacji, jak i koniugacji. Do częstych anomalii deklinacyjnych zaliczyła zmianę paradygmatu odmiany rzeczowników z jednej deklinacji na drugą, zwłaszcza rzeczowniki II deklinacji odmieniane według wzoru III deklinacji lub odwrotnie. Niektóre odstępstwa od normy klasycznej uzasadniła wpływem polszczyzny, opierając się (podobnie jak w innych częściach rozprawy) na ustaleniach, jakie poczyniła Krystyna Weyssenhoff-BrożKowa $(1991 ; 1998)$. Za $w$ ten sposób motywowaną zmianę uznała przede wszystkim zjawisko zmiany rodzaju rzeczownika. Na przykład genezy rodzaju nijakiego klasycznie żeńskich wyrazów dilatio, ercusatio, suspensio i protractio Zachara-Związek dopatrzyła się w rodzaju gramatycznym ich polskich ekwiwalentów (kolejno 'opóźnienie', ‘usprawiedliwienie się, 'zawieszenie', 'przedłużenie’), określając je jako kalki fleksyjne. Warto nadmienić, że wnioski o zmianie rodzaju rzeczownika łacińskiego pod wpływem polszczyzny Autorka wyciągnęła na podstawie przykładów powszechnie notowanych $w$ analizowanym materiale, natomiast $w$ przypadku pojedynczych wystąpień (np. potestas, domus, cingulum) za najbardziej prawdopodobną przyczynę uznawała błąd pisarza. Ponadto omówiła pokrótce nieregularności $w$ odmianie zaimka względnego i liczebników. W obrębie koniugacji zaobserwowała w księgach ławniczych trzy główne odstępstwa od normy łaciny klasycznej: tworzenie analitycznych form indicativi perfecti passivi z czasownikiem posiłkowym odmienionym w czasie przeszłym zamiast teraźniejszym (np. usus fuit zamiast usus est), budowanie form czasu perfecti na bazie tematu praesentis (possiderunt zamiast possederunt) oraz zmianę strony czasownika. W celu egzemplifikacji ostatniego zjawiska podała kilkanaście przykładów mających ilustrować tworzenie form strony zwrotnej od czasowników klasycznie występujących w stronie czynnej (s. 56-57). Należy jednak zaznaczyć, że w języku łacińskim gramatyczna kategoria strony może przybierać tylko dwie wartości: activum (strona czynna) i passivum (strona bierna) (Wolanin, 2012: 420), a o zurotności mówić można w kontekście diatezy nienacechowanej zwrotnej rozszerzającej zakres funkcjonalny wartości kategorii strony czynnej lub - rzadziej - biernej (w przypadku verba deponentia) przez występowanie współwykładnika $w$ postaci zaimka zwrotnego se (WolAniN, 2012: 427-428). Należałoby zatem mówić tutaj raczej o diatezie zwrotnej aniżeli o stronie zwrotnej, a ponadto wskazane byłoby wyróżnienie formacji, przy których końcówki aktywne i zaimek zwrotny se stanowią wykładnik dekauzatywizacji (WolanıN, 2012: 428-429). I choć samo zjawisko użycia czasowników z zaimkiem se było - co trafnie dostrzegła Zachara-Związek - częste $w$ polskiej łacinie średniowiecznej, głównie przez wpływ polszczyzny, jednak wskazane przez Autorkę exempla z ksiąg ławniczych Starej Warszawy budzą pewne zastrzeżenia. O ile niektóre przykłady, takie jak incipit se i se protestari, stanowią dobrą ilustrację omawianego zjawiska, gdyż $w$ łacinie klasycznej czasowniki te nie występowały z zaimkiem se, o tyle pozostałe są już dyskusyjne. Wyrażenia se sistere, se revocare, se dare, se recipere, se prestare czy najczęściej występujące $w$ analizowanym materiale se extendere - nawet jeśli $w$ nieco innym znaczeniu - używane były z zaimkiem zwrotnym również $w$ epoce starożytnej. Zatem, mimo że można byłoby mówić w odniesie- 
niu do niektórych przykładów o różnicy semantycznej, nie należałoby mówić o różnicy formalnej.

$\mathrm{Na}$ początku rozdziału trzeciego poświęconego zagadnieniom składniowym Zachara-Związek poczyniła dwa ważne zastrzeżenia dotyczące płaszczyzny syntaktycznej ksiąg ławniczych Starej Warszawy. Zwróciła uwagę na uproszczenie składni tych tekstów związane z ich pragmatycznym charakterem (np. rezygnacja ze składni accusativus cum infinitivo), a także podkreśliła formularny styl analizowanych zapisek skutkujący na przykład skracaniem często powtarzających się formuł lub wysoką frekwencją konstrukcji ablativus absolutus występującej $w$ kilku sformalizowanych zwrotach. Do najczęstszych składniowych anomalii zaliczyła niezachowywanie związku zgody pod względem rodzaju, liczby i przypadka między odnoszącymi się do siebie elementami wypowiedzi, popierając swój wywód przekonującymi przykładami. Za przyczynę analizowanych błędów uznała przede wszystkim pośpiech pisarza i jego niedostateczną znajomość gramatyki łacińskiej oraz wpływy języków narodowych. Następnie wskazała przykłady odmiennej niż w starożytności łączliwości przyimków. Przy okazji omawiania nieklasycznego łączenia przyimka ante z ablatiwem odnotowała przykład użycia tego przypadka do wyrażenia rozciągłości w czasie (debet servire quatuor annis 'musi służyć przez cztery lata'), sugerując odstępstwo od gramatyki klasycznej, gdyż - jak twierdzi - do określenia rozciągłości w czasie w łacinie starożytnej posługiwano się akuzatiwem (s. 63). Użycia ablatiwu w tej funkcji nie można jednak uznać za odstępstwo, wpisuje się ono bowiem w normy klasycznej gramatyki, która do wyrażenia wspomnianej rozciągłości dopuszczała użycie zarówno akuzatiwu, jak i ablatiwu (WolanıN, 2012: 241, 245). W dalszej części rozdziału Autorka omówiła nieprawidłowości w stosowaniu zaimków, przede wszystkim mylenie różnych ich typów i użycie niezgodne z zasadami klasycznymi. Zjawiska te nie były specyficzne tylko dla analizowanych ksiąg, lecz wpisywały się w ogólne tendencje łaciny średniowiecznej - zgodnie z przyjętą metodą zostały zatem omówione pokrótce. Ponadto Zachara-Związek poruszyła zagadnienie używania imiesłowów oraz składni accusativus cum infinitivo i ablativus absolutus.

W rozdziale czwartym Autorka dokonała systematyzacji poruszanych we wcześniejszych częściach opracowania zagadnień interferencji językowych z uwzględnieniem zależności przede wszystkim między łaciną a językami polskim i niemieckim oraz rozwinęła tę systematyzację. Omówiła najpierw nazwy własne - imiona, patronimika, przydomki oraz nazwy miejscowe - następnie wyrazy pospolite użyte $w$ charakterze glos, by przejść na końcu do przedstawienia kalk językowych - leksykalnych (słowotwórczych i semantycznych), frazeologicznych oraz gramatycznych (fleksyjnych i składniowych). W omawianiu tych ostatnich przyjęła kategoryzację zaproponowaną przez Weyssenhoff-BrożkowA (1991: 47-86). Glosy polskie oraz kalki leksykalne i frazeologiczne odnosiły się - jak wynika z przedstawionej analizy - najczęściej do terminów związanych z czynnościami prawnymi - te bowiem należało dookreślić terminem z języka wernakularnego bądź trzeba było utworzyć ich łaciński ekwiwalent. Swoją prezentację Autorka poparła wieloma przekonującymi przykładami, z których jeden budzi pewne zastrzeżenia. Za WeysSEnhoff-BrożkowA (1991: 79) uznała użycie wyrazu pecunia w liczbie mnogiej za kalkę składniową polskiego wyrazu „pieniądze”. Wprawdzie rzeczownik ten rzeczywiście występował przede wszystkim $w$ liczbie pojedynczej, należy jednak przypomnieć, że w znaczeniu 'pieniędzy' pojawiał się w liczbie mnogiej już w literaturze starożytnej (np. w dziełach Cycerona i Liwiusza). Polszczyzna mogła mieć 
zatem wpływ na częstsze średniowieczne użycie tego leksemu w pluralis, ale niekoniecznie musiała być czynnikiem decydującym. Z ostrożnością więc należy się odnosić do uznania tego przykładu za kalkę składniową.

Pomimo niektórych spornych interpretacji zjawisk językowych recenzowana praca zasługuje na uznanie i wysoką ocenę. Dzięki wyraźnemu wyodrębnieniu analizowanych płaszczyzn poruszane zagadnienia zostały przedstawione w sposób uporządkowany i systematyczny. Szczególnym atutem pracy jest zogniskowanie analizy na charakterystycznych cechach języka badanego materiału i przedstawienie ich na tle ogólnych zjawisk występujących $w$ łacinie średniowiecznej, a także pokazanie, $w$ jakim stopniu owe ogólne tendencje realizują się w analizowanych księgach. Dzięki temu z jednej strony zweryfikowane zostały wcześniejsze ustalenia innych badaczy dotyczące cech łaciny okresu średniowiecza, z drugiej natomiast na przykładzie nieomawianych wcześniej w perspektywie lingwistycznej ksiąg ławniczych przedstawiona została charakterystyka językowa tekstów pragmatycznych. Na ogół trafnie dobrane przykłady każdorazowo opatrzone zostały przypisem odsyłającym do lokalizacji $w$ księdze. Wart podkreślenia jest aspekt komparatystyczny recenzowanej publikacji także w obrębie samych ksiąg ławniczych. Autorka bowiem nie tylko zwracała uwagę na różnice między ogólnymi tendencjami zachodzącymi $w$ łacinie średniowiecznej a tymi $w$ badanych tekstach, ale wskazywała również na cechy typowe dla konkretnego pisarza danej księgi, rozpatrując je $w$ kontekście jego sprawności językowej. Warto nadmienić, że w książce zamieszczonych zostało również kilka fotografii analizowanych rękopisów, które pozwalają zapoznać się na przykład ze sposobem pisania poszczególnych pisarzy. Na końcu pracy określonej przez samą Autorkę mianem „wstępu do dalszych badań nad językowym obrazem społeczności mieszkańców Starej Warszawy" (s. 103) wskazano postulat badawczy dotyczący „analizy językowej zachowanych ksiąg innych miast na Mazowszu, a potem w całej Koronie” (s. 103), co „pozwoliłoby stworzyć językowy obraz ośrodków miejskich i lepiej uchwycić jego specyfikę" (s. 103). Pozostaje zatem wyrazić nadzieję, że podjęte badania będą kontynuowane, a ich wyniki zostaną przedstawione w równie ciekawych i wartościowych publikacjach.

\section{Literatura}

Bartoszewicz A., red., 2020: Księgi ławnicze Starej Warszawy z lat 1453-1535. Wydawnictwo Uniwersytetu Warszawskiego. Warszawa.

Nowa K., 2017: Ciemna, szpetna, zepsuta. Norma i anomalia $w$ opisie łaciny średniowiecznej. „Biuletyn Polskiego Towarzystwa Językoznawczego" LXXIII, s. 161-174.

Weyssenhoff-Brożkowa K., 1991: Wpływ polszczyzny na łacinę średniowieczna w Polsce. Polska Akademia Nauk - Instytut Języka Polskiego. Kraków.

Weyssenhoff-Brożkowa K., 1998: Studia nad łacina średniowieczna $w$ Polsce. Ośrodek Badań nad Tradycją Antyczną w Polsce i w Europie Środkowo-Wschodniej. Warszawa.

Wolanin H., 2012: Gramatyka opisowa klasycznej łaciny w ujęciu strukturalnym. Księgarnia Akademicka. Kraków. 